\title{
Latin American perspective
}

\author{
Eduardo Bianco
}

Correspondence to

Dr Eduardo Bianco, The Research Center of the Tobacco Epidemic, Montevideo, Uruguay; biancoeduardo1@gmail.com

Received 16 January 2022 Accepted 17 January 2022

\section{Check for updates}

(c) Author(s) (or their employer(s)) 2022. No commercial re-use. See rights and permissions. Published by BMJ.

To cite: Bianco E. Tob Control 2022;31:385.
The first 20 years of the 21 st century have shown great progress on tobacco control, including a significant drop in regional prevalence, under the influence of the WHO FCTC. But the tobacco problem is far from being resolved. ${ }^{1}$ In the last 5 years, the progress has slowed down and policies 'beyond $\mathrm{MoH}$ ' (tobacco taxes, Total Advertising Ban, ITP implementation) remain to be very difficult to obtain. ${ }^{2}$

The tobacco industry (TI), that 10 years ago seemed to be 'on the ropes' has reinvented itself and fought back, putting us in 'check' with its 'harm reduction' ${ }^{34}$ strategy and is menacing to deploy all its firepower to divide the tobacco control movement at COP10.

It remains as the main obstacle for tobacco control policies development and implementation, ${ }^{5}$ to which we should add that in most countries there is a lack of structural capacity, lack of policy coherence and lack of self-financing for tobacco control.

Our region has been very dependent on international economic aid (eg, Bloomberg Foundation) to make progress. Until when will it be kept? What will happen when it decreases or disappears? How to defend what has been achieved, continue advancing and ensure sustainability?

Up to date, we have advanced by 'pushes', achieving the implementation of one or two provisions of the FCTC in a country, at a certain moment. But most countries lack a National Coordination Mechanism (NCM) that could allow sustained technical and political (interministerial) as well as civil society and academia participation. That would be a great tool for supporting the young generation of regional advocates and leaders to reach further progresses.

It is time to fight for NCM and for a proper FCTC Art.5.3 guidelines implementation, to make it possible to advance rapidly in policies that go beyond the $\mathrm{MoH}$ (including 'endgame' strategies) and to ensure tobacco control sustainability.
In my opinion, this combination would be essential to face the challenges and promote significant advances in tobacco control in the next 10 to 20 years.

While we work on it, we must continue to apply the 'domino effect' strategy to move forward: identify a candidate country for passing a certain disposition, focus our efforts on that to prepare itincluding investment-and make it a 'model to be followed'.

Some final words on smoking cessation. The TI 'harm reduction' exploits our weaknesses in smoking cessation and the lack of funding by donors to search innovative approaches. We do need to change that situation very soon and put cessation outside TI hands.

\section{Twitter Eduardo Bianco @bi}

Funding The authors have not declared a specific grant for this research from any funding agency in the public, commercial or not-for-profit sectors.

Competing interests None declared.

Patient consent for publication Not applicable.

Ethics approval This study does not involve human participants.

Provenance and peer review Commissioned; internally peer reviewed.

ORCID iD

Eduardo Bianco http://orcid.org/0000-0002-8284-5132

\section{REFERENCES}

1 Sandoval RC, Bacelar Gomes A, Roche M. Avances en El control de tabaco en La Región de las Américas 2020. Rev Panam Salud Publica 2021;45:e94:1.

2 Blanco A, Sandoval RC, Martínez-López L. [Ten years of the WHO Framework Convention on Tobacco Control: progress in the Americas]. Salud Publica Mex 2017;59Suppl 1:S117-25 http://doi. org/10.21149/8682

3 Available: https://www.bmj.com/bmj/section-pdf/187715?path=/ bmj/346/7889/Analysis.full.pdf

4 Available: https://www.altria.com/moving-beyond-smoking/reducethe-harm-of-tobacco-products

5 Available: https://tobaccotactics.org/wiki/latin-america-andcaribbean-region/ 